\title{
Persepsi Ibu Muda dan Keluarga tentang Pemberian Imunisasi (Pendekatan Maternal Sensitivity Models Berbasis Keluarga)
}

\author{
Diyan Indriyani ${ }^{1 *}$, Susi Wahyuning Asih ${ }^{1}$ \\ ${ }^{1}$ Faculty of Health Sciences Muhammadiyah University Jember, Indonesia \\ E-mail : ${ }^{1}$ dieindri@yahoo.com*, ${ }^{2}$ susiwahyuningasih@ymail.com
}

\begin{abstract}
Introduction: The health condition of babies is the responsibility of mothers and the family. One effort to avoid a situation of pain in infants is by immunization. Early mothers with infant care experience is still lacking, need to support the family in order to have proper decision-making ability in the care of babies, one of which is immunization. Therefore, the right perception about immunization in infants is critical owned by the mother and the family. Objective: This study has the objective to explore the perceptions of early mothers and families about immunization approach to maternal sensitivity models. Methods: The research design was participatory research approaches (qualitative) and Participatory Action Reseacrh (PRA). The techniques of data collection was Focus Group Discussion (FGD) with 50 early mothers as the participants in Regional Health Center of Sumbersari and Sukorambi Jember who had babies. The sampling was done by using purposive sampling in March-August 2016. The data werethen analyzed using descriptive and qualitative methods. Results: The result showed the general condition of pain often experienced by babies are acute respiratory infections, diarrhea and febrile, although some cases of pneumonia occur. Health official are already running a baby care related programs such as immunization, immunization coverage has been good and meet the target. Perceptions of early mothers about immunizations include: to schedule and type of immunization tend to succumb to the health and family perception about immunization is likely to depend wife and health official. Conclusion: It is concluded that immunization coverage has been on target, but the perception of early mothers and families about immunization still needs to be improved. Recommendations in this research that suggested that synergism cooperation among health official, early mothers and families in the optimization of the perception about immunization.
\end{abstract}

Keywords: Early Mothers and Family, Infant Immunization, Maternal sensitivity Models, Perception.

\section{Pendahuluan}

Menjadi seorang ibu merupakan tugas perkembangan yang akan dilalui perempuan dalam sebuah rumah tangga. Berbagai aktifitas akan dijalani, dengan tujuan utama yaitu menjaga keberlangsungan keluarga yang salah satunya adalah dalam hal kesehatan. Anggota keluarga yang akan selalu berinteraksi dalam sebuah keluarga tentunya mulai dari suami dan anak yang dilahirkannya.

Ibu yang masih memiliki usia belia (muda) dengan tanggungjawab asuh seorang bayi, tentu memerlukan kemampuan yang kompleks agar bayinya tetap dalam kondisi sehat dan bebas dari sakit. Salah satu upaya untuk mencegah kejadian sakit pada bayi adalah dengan tindakan imunisasi. Imunisasi pada bayi sangatlah penting dilakukan sebagai upaya preventif dari masuknya kuman yang berisiko menimbulkan kejadian sakit. Jenis penyakit yang memiliki peluang dapat dicegah oleh imunisasi antara lain adalah penyakit Tuberklosis (TBC), Dipteri, Folio, Hepatitis, Tetanus, Pertusis, Campak. Agar ibu menjalankan perannya secara optimal, maka persepsi yang positif tentang imunisasi pada bayi juga sangat diperlukan. Menurut Samson dan Lewis dikatakan bahwa peran merawat bayi tentunya juga tidak lepas dari pengalaman ibu dalam memberikan perawatan pada bayi. Pengalaman setiap ibu berbeda-beda dalam merawat bayi (Bobak, Lowdermilk \& Jansen, 2005).

Imunisasi merupakan salah satu investasi kesehatan yang paling cost-effective (rnurah), karena terbukti dapat mencegah dan mengurangi kejadian sakit, cacat, dan kematian akibat PD3lyang diperkirakan 2 hingga 3 juta kematian tiap tahunnya (Kemenkes RI, 2016). Pada tahun 2013, kasus Campak meningkat mencapai 2.529 dan pada tahun 2014 kembali turun mencapai 762 kasus (Kemenkes RI, 2014). Berdasarkan data yang dilansir oleh Kementerian Kesehatan RI, cakupan Imunisasi Dasar Lengkap (IDL) masih mencapai angka 86,8\% pada April 2015. Sedangkan pada tahun 2019, Kemenkes menargetkan cakupa imunisasi perlu ditingkatkan hingga mencapai target $93 \%$. Fakta di lapangan menunjukkan bahwa masih ada 
kelompok masyarakat yang belum terjangkau oleh pelayanan kesehatan (Finaziz, 2016). Indikator RPJMN untuk program imunisasi yaitu persentase kabupaten/kota mencapai $80 \%$ imunisasi dasar lengkap pada bayi. Pada tahun 2015 sebanyak 292 kabupaten/kota $(56,8 \%)$ telah mencapai $80 \%$ imunisasi dasar lengkap pada bayi, dengan demikian target RPJMN pada tahun 2015 sebesar $75 \%$ belum tercapai.

Indonesia berkomitmen pada lingkup ASEAN dan SEARO bahwa dalam rangka mencapai target eliminasi campak tahun 2020, diperlukan cakupan imunisasi campak minimal 95\% secara merata di seluruh kabupaten/kota. Hal itu terkait dengan realita bahwa campak merupakan penyebab utama kematian pada balita. Kasus campak di Indonesia merupakan 10 penyakit terbesar penyebab kematian pada anak usia 29 hari 4 tahun (Kemenkes, 2016).

Target pelayanan bayi paripurna selama 5 (lima) tahun telah tercapai. Pelayanan bayi ini berkaitan erat dengan cakupan Kunjungan Neonatal (KN) Lengkap. Cakupan (kunjungan) bayi Provinsi Jawa Timur pada tahun 2014 mencapai $95,43 \%$, dan hanya 3 (tiga) kabupaten/kota belum mencapai target yang ditentukan (90\%). Kabupaten/kota tersebut adalah Kota Blitar, Kabupaten Jember dan Kabupaten Situbondo ((Kemenkes, 2014) Mengingat bayi merupakan kelompok usia yang sangat rentan terhadap kondisi sakit, karena imunitas yang masih rendah, maka tindakan pemberian imunisasi sangatlah penting untuk dilakukan. Untuk tercapainya pemberian imunisasi dasar lengkap pada bayi sangat diperlukan peran ibu dan pasangan (keluarga) (Indriyani, Asmuji dan Wahyuni , 2016) Ibu muda memiliki risiko pengalaman yang masih minimal dalam pola asuh bayi, termasuk dalam mencapai target pemberian imunisasi dasar lengkap, sangat membutuhkan dukungan yang positif dari keluarga.

Menurut Indriyani (2013) keluarga adalah salah satu institusi masyarakat yang paling penting. Keluarga mengemban tanggungjawab utama yang memiliki fungsi biologis, fungsi ekonomi, fungsi pendidikan, fungsi psikologi dan fungsi sosiobudaya. Melalui dukungan keluarga yang positif, akan berdampak pola hubungan yang positif dari seluruh anggota keluarga.

Keluarga yang memiliki persepsi positif tentang imunisasi pada bayi, memiliki peluang untuk membangun perilakuknya sesuai dengan pemahaman keluarga dalam memberikan dukungan. Berbagai dukungan akan diberikan, misalnya mengingatkan jadwal, mengantar pasangan dalam kegiatan imunisasi bayi dan lain-lain. Hal ini selaras dengan penelitian Utami dan Yasin (2014) yang mendapatkan hasil adanya hubungan dukungan keluarga dengan motivasi ibu dalam mendapatkan imunisasi dasar lengkap pada bayi usia 0-12 bulan di Desa Nyabakan Barat. Selain itu juga terdapat penelitian serupa yang dilakukan oleh Ritonga, Syarifah dan Tukiman (2014) diperoleh hasil adanya hubungan dukungan keluarga dengan kepatuhan ibu melaksanakan imunisasi dasar pada anak.

Ibu muda yang tinggal di pedesaan memiliki risiko yang berkaitan dengan kurangnya informasi dan pengguna budaya yang sangat lekat khususnya dalam hal perawatan bayi. Berkaitan dengan pemecahan permasalahan tersebut di atas, maka peneliti ingin mengekplorasi lebih lanjut tentang persepsi tentang imunisasi pada bayi yang difokuskan pada ibu muda dengan melibatkan keluarga sebagai social support. Penelitian ini pendekatan yang digunakan yaitu Maternal Sensitivity Models berbasis keluarga. Adapun masalah yang diteliti adalah berkaitan dengan persepsi ibu muda dan keluarga tentang imunisasi pada bayi.

\section{Metode}

Penelitian ini dilakukan dengan pendekatan penelitian partisipatif (kualitatif) dan Participatory Action Reseacrh (PRA). Tehnik pengumpulan data dilakukan dengan cara FGD dan indept interview pada ibu muda dan keluarganya di Wilayah Puskesmas Sumbersari dan Sukorambi sejumlah 50 partisipan. Adapun tehnik pengambilan sampel dilakukan secara Purposive Sampling. Kurun waktu pengambilan data dimulai pada bulan MaretAgustus 2016. Instumen penelitian dilakukan menggunakan lembar pengumpul data Analisis data yang digunakan yaitu pada data 
ISSN : 2354-5852

e-ISSN : 2579-5783

umum menggunakan analisis deskriptif dan pada data khusus diolah secara kualitatif.

\section{Hasil dan pembahasan}

\subsection{Hasil Penelitian}

Hasil penelitian ini terdiri dari distribusi frekuensi riwayat sakit, jenis sakit pada bayi di Puskesmas Sumbersari dan Sukorambi, dan hasil FGD. Berkaitan dengan hasil penelitian, maka didapatkan gambaran data sebagai berikut:

Tabel 1. Distribusi Frekuensi Riwayat Sakit Pada Bayi Responden di Wilayah Puskesmas Sumbersari dan Sukorambi Kabupaten Jember Tahun 2016

\begin{tabular}{lrcrr}
\hline $\begin{array}{l}\text { Riwayat Sakit Pada Bayi di } \\
\text { PKM Sumbersari }\end{array}$ & \multirow{2}{*}{ Jumlah } & $\begin{array}{l}\text { Riwayat Sakit Pada Bayi di } \\
\text { PKM Sukorambi }\end{array}$ & Jumlah & $(\%)$ \\
\hline Pernah & 18 & 72.0 Pernah & 22 & 88.0 \\
Tidak pernah & 7 & 28.0 Tidak pernah & 3 & 12.0 \\
Total & 25 & 100.0 Total & 25 & 100.0 \\
\hline
\end{tabular}

Berdasarkan tabel 1 didapatkan riwayat sakit pada bayi responden di Wilayah Puskesmas Sumbersari sebagian besar pernah sakit yaitu sebanyak 18 responden (72\%), sedangkan responden di Wilayah Puskesmas Sukorambi mayoritas juga bayinya pernah sakit yaitu sebanyak 22 responden (88\%).

Tabel 2. Distribusi Frekuensi Riwayat Jenis Sakit Pada Bayi Responden di Wilayah Puskesmas Sumbersari dan Sukorambi Kabupaten Jember Tahun 2016

\begin{tabular}{|c|c|c|c|c|}
\hline $\begin{array}{l}\text { Riwayat Jenis Sakit Pada Bayi di } \\
\text { PKM Sumbersari }\end{array}$ & Jumlah & $\begin{array}{l}\text { Riwayat Jenis Sakit Pada Bayi di } \\
\text { PKM Sukorambi }\end{array}$ & Jumlah & $(\%)$ \\
\hline ISPA & 14 & 56.0 ISPA & 15 & 60.0 \\
\hline Diare & 4 & 16.0 Diare & 4 & 16.0 \\
\hline Febris & 0 & 0 Febris & 3 & 12.0 \\
\hline Tidak sakit & 7 & 28.0 Tidak Sakit & 3 & 12.0 \\
\hline Total & 25 & 100.0 Total & 25 & 100.0 \\
\hline
\end{tabular}

Menurut tabel 2 didapatkan jenis riwayat sakit pada bayi responden di Wilayah Puskesmas Sumbersari jumlah terbanyak yaitu ISPA yaitu sebanyak 14 responden

\section{Hasil FGD dengan Responden di Wilayah Sumbersari}

Peneliti membahas tema imunisasi pada bayi 0-12 bulan. Melalui FGD bersama responden peneliti mendapatan informasi antara lain adalah: 1) imunisasi dilakukan lengkap sesuai jadwal, 2) jenis imunisasi: $\mathrm{Hb}$, hepatitis, BCG (fungsi tidak tahu namun ada yang menyebutkan untuk TBC) dan terbaik diberikan usia 1minggu, DPT (fungsi tidak tahu), campak, polio, $\mathrm{HbO}$, yang ingat adalah
(56\%), demikian juga pada responden di Wilayah Puskesmas Sukorambi sebagian besar bayinya pernah sakit ISPA yaitu sebanyak 15 responden $(60 \%)$.

saat bayi usia 9 bulan yaitu imunisasi campak, 3) imunisasi dimulai dengan imunisasi TT, yaitu sebanyak 2 kali saat ibu hamil bulan dan 7 bulan, 4) imunisasi perlu dilakukan untuk kekebalan bayi, dan 5) tentang jadwal imunisasi kurang paham, selama ini buku KIA disodorkan dan imunisasi terserah bidannya

\section{Hasil FGD dengan Responden di Wilayah Sukorambi}

Imunisasi merupakan upaya preventif yang perlu dilakukan dalam perawatan bayi. 
Melalui diskusi peneliti mendapatkan gambaran upaya preventif dan persepsi responden terkait imunisasi bayi. Ungkapan responden tentang imunisasi bayi yaitu: 1) bayi diimunisasi sudah sesuai jadwal, 2) munisasi perlu dilakukan, 3) tujuan imunisasi adalah untuk kekebalan,kesehatan, menghindari penyakit, 4) jenis imunisasi: campak, BCG (untuk mencegah penyakit paru-paru, diberikan saat baru lahir), folio, $\mathrm{Hb}, 5$ ) informasi tentang imunisasi sudah ada di buku warna merah muda (buku KIA), sudah dibaca tapi lupa, 6) selama ini terkait imunisasi responden hanya datang dengan membawa buku KIA, dan 7) terkait jadwal imuniasi responden tidak menandai, selama ini tergantung bidannya

\section{Hasil FGD dengan Keluarga Responden di Wilayah Sumbersari}

Imunisasi merupakan upaya preventif yang penting dilakukan untuk mencegah kejadian sakit pada bayi. Saat peneliti membahas tema ini, diperoleh data antara lain: 1) Dilakukan imunisai sesuai jadwal, 2) fungsi imunisasisebagai proteksi, kekebalan tubuh, 3) semua bayi telah diimunisasi dengan jadwal mengikuti program posyandu, 4) tergantung petugas kesehatan tentang jenis imunisasi dan waktu pelaksanaannya, suami tidak begitu jelas, 5) tentang imunisasi dapat dilihat di buku KIA, dan 6) jenis imunisasi pertama BCG, dan 7) pemberian imunisasi DPT dengan syarat badan bayi tidak panas.

\section{Hasil FGD dengan Keluarga Responden di Wilayah Sukorambi}

Peneliti juga berdiskusi dengan responden tentang imunisasi pada bayi. Hasil diskusi tentang imunisasi didapatkan gambaran data yaitu: 1) jenis imunisasi: folio, hepatitis, campak, DPT (belumtahu kegunaan), 2) bila bayi panas maka imunisasi DPT ditunda, 3) secara jadwal untuk imunisasi suami tidak paham, biasanya justru istri yang hafal, 4) Suami tidak melarang istri datang ke posyandu, 5) ke posyandu ibu biasanya jalan sendiri karena dekat, 6) setelah kegiatan posyandu, suami hampir tidak pernah menanyakan hasil pemeriksaan bayi saat di posyandu, 7) informasi imunisasi bertanya ke Puskesmas, dan 8) panduan imunisasi ada di buku KIA.

\section{Maternal Sensitivity Models Berbasis Keluarga}

Maternal sensitivity models berbasis keluarga dalam optimalisasi competence baby care, memiliki bagan yang dapat digambarkan sebagai berikut: 
ISSN : 2354-5852

e-ISSN : 2579-5783

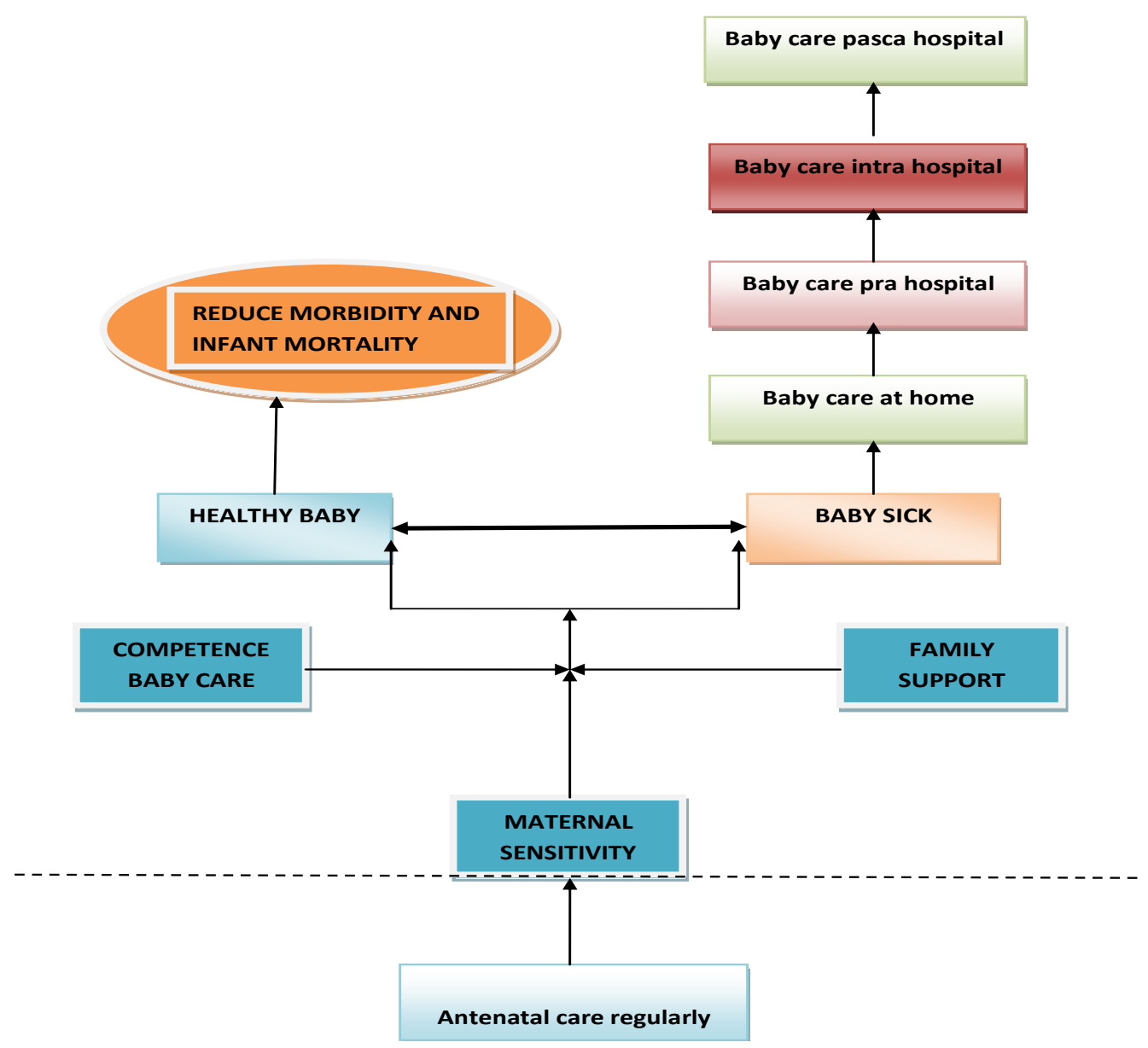

Bagan 1. Maternal Sensitivity Models Berbasis Keluarga Dalam Optimalisasi Competence Baby Care Pada Ibu Muda di Pedesaan

Berkaitan dengan draft models tersebut di atas, dapat dijabarkan antara lain adalah:

a. Kondisi bayi sehat dan sakit merupakan suatu rentang yang bersifat continuum. Konstanta sehat sakit pada bayi sangat tergantung pada situasi kesehatan bayi berada pada situasi lingkungan yang ada.

b. Bayi merupakan kelompok usia yang sangat rentan mengalami ancaman kesakitan dan kematian.

c. Ibu merupakan perawat terbaik bagi bayi dalam mempertahankan status kesehatan termasuk mencapai fungsi pertumbuhan dan perkembangan yang optimal. d. Kepekaan ibu dalam mengenal perubahan status kesehatan bayi sangat diperlukan untuk mengkondisikan penanganan yang tepat saat bayi berada dalam lingkungan rumah, pra hospital, intra hospital dan pasca hospital.

e. Ibu harus memiliki kemampuan optimal dalam perawatan bayi.

f. Keluarga merupakan kelompok pendukung yang tidak bisa dipisahkan dari lingkungan ibubayi.

Adapun langkah-langkah dalam penerapan maternal sensitivity Models berbasis keluarga ini adalah:

a. Ibu hamil diberikan motivasi melakukan antenatal care secara rutin, sehingga bisa diketahui 
kondisi tingkat kesejahteraan ibu dan janin.

b. Ibu mengikuti kelas prenatal dan kegiatan edukasi selama masa antenatal

c. Ibu diberikan motivasi melakukan persalinan di pelayan kesehatan

d. Petugas kesehatan melaukan edukasi postnatal dengan pendekatan FCMC tentang perawatan bayi baru lahir, dengan melibatkan keluarga sebagai family and social support.

e. Ibu dan keluarga diajarkan tentang review baby care, serta pengenalan kondisi baby sick.

\subsection{Pembahasan}

Imunisasi pada bayi merupakan upaya preventif yang sangat penting dalam mencegah kejadian sakit. Jenis penyakit yang dapat dicegah dengan imunisasi terseb t antara lain adalah penyakit Tuberkulosis, Dipteri, Folio, Hepatitis, Tetanus, Pertusis dan Campak. Hasil penelitian menunjukkan bahwa keseluruhan ibu menyatakan melakukan imunisasi pada bayi sesuai dengan jadwal yang tertera di buku KIA namun sebagian besar ibu belum memahami untuk apa imunisasi tersebut, berapa kali diberikan, manfaat yang didapatkan, dan waktu pemberiannya. Ibu hanya sebatas mengetahui bahwa imunisasi penting diberikan pada bayi dan menyerahkan semuanya pada petugas kesehatan untuk memberikan imunisasi sesuai jadwal. Hasil ini didukung oleh penelitian Keller (2008) mengenai persepsi orang tua di Meksiko-Amerika mengenai imunisasi pada bayi yang diberikan oleh perawat yang menunjukkan hasil bahwa kepercayaan terhadap petugas kesehatan menjadi tema utama yang muncul dari penelitian dan membangun hubungan percaya diri antara ibu dan bayi. Imunisasi merupakan proses memberikan vaksin ke dalam tubuh bayi yang biasanya meninbulkan efek atau reaksi tertentu dari bayi sehingga hubungan saling percaya antara ibu dan petugas kesehatan memang harus diutamakan. f. Ibu dan keluarga diajarkan tentang kemampuan dalam pengambilan keputusan saat masa baby sick.

g. Ibu dan keluarga melakukan upaya perawatan bayi dengan tehnik pendekatan upaya perawatan bayi secara benar menggunakan media booklet.

h. Ibu dan keluarga melakukan pemantauan terhadap kondisi pertumbuhan dan perkembangan bayi.

i. Petugas kesehatan dalam memberikan edukasi tentang perawatan bayi, menggunakan media Modul Perawatan Bayi.

Namun yang tidak kalah penting adalah manfaat imunisasi tersebut dan jadwal imunisasi yang tepat. Seharusnya ibu dan keluarga memahami dengan benar apa saja jenis imunisasi yang diberikan pada bayi, manfaatnya apa saja, kapan dan berapa kali imunisasi tersebut diberikan karena. Hal tersebut merupakan tugas dan tanggung jawab orang tua untuk memastikan bahwa bayi aman dari faktor kesalahan pemberian imunisasi. Jadwal imunisasi memang telah tertera di buku KIA namun pada kenyatannya ibu dan keluarga jarang membaca buku tersebut sehingga tidak paham mengenai imunisasi secara lengkap. Ibu dan keluarga mengetahui jadwal imunisasi karena diberitahu oleh kader jika waktunya imunisasi, mereka mendatangi posyandu dan melakukan imunisasi. Mengenai imunisasi apa yang akan diberikan, bagaimana pemberiannya, manfaatnya dan lain sebagainya ibu tidak memahami dengan benar. Seharusnya keberhasilan pencapaian imunisasi tersebut selaras dengan pemahaman ibu dan keluarga mengenai informasi lengkap terkait dengan imunisasi yang diberikan. Pentingnya ibu dan keluarga memiliki persepsi yang baik dan tepat tentang imunisasi pada bayi, hal ini selaras dengan penelitian Syahputra (2011) bahwa ada hubungan sikap terhadap pemberian imunisasi dasar pada bayi di Wilayah Kerja Puskesmas Kuta Baro Aceh Besar. Selain itu ada peneliti lain Paridawati, Rachman, dan Fajarwati, (2012) yang juga 
menguatkan hasil penelitian bahwa Pendidikan ibu $(\mathrm{P}=0,048)$, pengetahuan ibu $(\mathrm{P}=0,027)$, sikap ibu $(\mathrm{P}=0,042)$, ketepatan pelayanan $(\mathrm{P}=0,044)$, dukungan keluarga $(\mathrm{P}=0,042)$ berhubungan dengan tindakan pemberian imunisasi dasar pada bayi/anak.

Persepsi yang positif dari ibu muda dan keluarga tentang pentingnya imunisasi, dan hal-hal yang terkait dengan imunisasi pada bayi merupakan faktor pendukung untuk keberhasilan pemberian imunisasi. Selain keluarga tentu petugas kesehatan juga memiliki peran penting untuk mengkondisikan ibu dan keluarga memiliki persepsi yang baik tentang imunisasi, datang ke pelayanan Posyandu dan pelayanan kesehatan lain dalam rangka pemberian imunisasi. Salah satu pendekatan yang bisa digunakan oleh petugas kesehatan dalam mengoptimalkan persepsi ibu dan keluarga serta cakupan imunisasi adalah menggunakan Maternal Sensitivity Models (MSM) berbasis keluarga. Melalui pendekatan model ini, petugas kesehatan melakukan berbagai program untuk mangasah persepsi ibu tentang perawatan bayi, optimalisasi kesehatan, pengenalan kejadian sakit pada bayi dan lainlain. Melalui persepsi ini diharapkan ibu akan memiliki kepekaan yang lebih baik dalam menilai kondisi perubahan kesehatan bayi, pengambilan keputusan dan tempat mencari bantuan pertolongan. Selain itu keluarga juga diperkenalkan dengan upaya-upaya preventif dalam mencegah kejadian sakit pada bayi. Salah satu upaya preventif tersebut adalah ibu dan keluarga sadar akan pentingnya imunisasi. Keluarga dalam hal ini menjadi supporter yang sangat penting bagi ibu dalam menguatkan perilaku ibu, memberi dukungan juga dorongan dalam setiap pengambilan keputusan terkait masalah kesehatan bayi, termasuk perilaku mencegah penyakit yang dapat dicegah dengan imunisasi (PD3I).

\section{Kesimpulan}

Berdasarkan hasil penelitian, maka dapat dsimpulkan sebagai berikut: 1) Secara umum kondisi sakit yang sering dialami oleh bayi di wilayah Puskesmas Sumbersari dan Sukorambi Jember adalah ISPA, diare, febris. Meskipun beberapa kasus terjadi gangguan pernapasan yang lebih serius dalam bentuk pnemonia, 2) Puskesmas dan petugas kesehatan sudah menjalankan program terkait pelayanan bayi seperti imunisasi, Cakupan imunisasi sudah baik dan memenuhi target, 3) Persepsi ibu muda masalah imunisasi untuk jadwal dan jenis imunisasi cenderung menyerahkan kepada petugas kesehatan, dan 4) Persepsi keluarga tentang imunisasi cederung tergantung istri dan petugas kesehatan.

Saran pada penelitian ini adalah keluarga sebaga supporter utama dalam membangun perilaku anggota keluarga dapat mendukung melalui dukungan informasional, material, dan emosional. Dukungan ini dapat diberikan selama periode perinatal, termasuk ketercapaian imunisasi dasar pada bayi, dan untuk tenaga kesehatan perlu upaya menyusun strategi membangun persepsi masyarakat tentang imunisasi dengan model mengaktifkan kepekaan ibu tentang kesehatan bayinya, serta melibatkan keluarga secara langsung sebagi social support. Maternal sensitivity models bisa digunakan sebagai salah satu pendekatan dalam menjalankan program imunisasi.

\section{Daftar pustaka}

Bobak, LM., Lowdermilk, D.L., \& Jensen, M.D., (2005). (Alih Bahasa * Wijayarini, M.A). Buku Ajar Keperawatn Maternitas. Edisi 4. Jakarta : EGC

Faber, M \& Benade, S.A.J. (2001). Perceptions of infant cereals and dietary intakes of children aged 4-24 months in a rural South African community. International Journal of Food Sciences and Nutrition. 52, 359365.

DOI: 10.1080/09637480120057594

Finazis, R. (2016). Tingkatkan Cakupan Imunisasi di Indonesia. Unair News. http://news.unair.ac.id. Diakses 10 Maret 2017.

Indriyani, D. (2013). Keperawatan Maternitas Pada Area Perawatan Antenatal. Edisi Pertama. Yogyakarta: Graha Ilmu 
Indriyani, D \& Asmuji. (2014). Model Edukasi Postnatal Melalui Pendekatan FCMC sebagai Strategi Optimalisasi Competence Mothering dalam Menurunkan Angka Kematian Ibu dan Bayi di Kabupaten Jember. Jurnal Keperawatan. Vol 2. No. 2 Desember 2014. Malang: FIKes UM Malang.

Indriyani, D., dan Asmuji. (2014). Upaya Promotif dan Preventif dalam menurunkan AKI dan AKB. Yogyakarta: Arruz Media.

Indriyani, D, Asmuji dan Wahyuni, S. (2016). Edukasi Postnatal Dengan Pendekatan Family Centered Maternity Care (FCMC). Cetakan Pertama. Yogyakarta: Graha Ilmu

Keller, T. (2008). Mexican American parent's perceptions of culturally congruent interpersonal processes of care during childhood immunization episodes: A pilot study. Online Journal of Rural Nursing and Health Care, vol. 8, no. 2, Fall 2008.

Kemenkes RI. (2012). SDKI. (2012). Jakarta: Kementrian Kesehatan RI.

Kemenkes RI. (2014). Profil Kesehatan Propinsi Jawwa Timur 2014.. www.depkes.go.id. Diakses 10 Maret 2017.

Kemenkes RI. (2016). Info Datin. Pusat data Dan Informasi Kementerian RI. Situasi Imunisasi di Indonesia. Hari Imunisasi 2016. ISSN 2442-7659. http://www.depkes.go.id. Diakses 10 Maret 2017.

Paridawati., Rachman, WA dan Fajarwati, I. (2012). Faktor Yang Berhubungan Dengan Tindakan Ibu Dalam Pemberian Imunisasi Dasar Pada Bayi Di Wilayah Kerja Puskesmas Bajeng Kecamatan Bajeng Kabupaten Gowa. http://repository.unhas.ac.id. Diakses 10 maret 2017.

Ritonga, MRS., Syarifah dan Tukiman. (2014). Hubungan Dukungan Keluarga Dengan Kepatuhan Ibu Melaksanakan Imunisasi Dasar Pada Anak Di Desa Tigabolon Kecamatan Sidamanik Kabupaten Simalungun 2014. jurnal.usu.ac.id. Diakses 6 Maret 2017
Syahputra, J. (2011). Hubungan Antara Pengetahuan dan Sikap Ibu Terhadap Imunisasi dasar Pada Bayi di Wilayah Puskesmas Kuta Baro Aceh Besar. http://etd.unsyiah.ac.id. Diakses tanggal 6 Maret 2017

Utami, R dan Yasin, Z. (2014). Hubungan Dukungan Keluarga Dengan Motivasi Ibu Dalam Mendapatkan Imunisasi Dasar Lengkap Pada Bayi Usia 0-12 Bulan Di Desa Nyabakan Barat https://ejournal.wiraraja.ac.id. Diakses 10 Maret 2017 